\title{
Olvasottsági statisztikák
}

\author{
Visitor statistics
}

doi: 10.24365/ef.v60i4.514

Jelen lapszámunkban „Szakmai vezetőknek 1 percben" címmel új rovatot indítunk, amelyben különböző népegészségügyi témákban rövid összefoglalókat ajánlunk egészségügyi vezetők számára. Az új rovat első írásának témája az ischaemiás szívbetegség elsődleges megelőzése.

A szerkesztőség a lap fennállásának 60. évfordulója alkalmából meghívja szerzőit, hogy pályázzanak a lapban megjelent közleményükkel előadás megtartására. A nyertes cikkek szerzői a folyóirat jubileumi konferenciáján mutathatják be munkájukat. Bővebb információ a pályázati felhívásban olvasható.
A látogatói és olvasottsági statisztikákat a már megszokott módon ismertetjük. Az ábra mutatja a weboldal látogatóinak havi számát, illetve az átlagos napi értékeket. A számok a szerkesztőség örömére azt mutatják, hogy a lap olvasottsága folyamatosan növekszik. A TOP 10-es listák alapján arra következtethetünk, hogy összességében az iskolai egészségfejlesztéssel kapcsolatos írások a legnépszerübbek. Ez a téma a három 10-es rangsorban összesen 11 alkalommal szerepel.

Várjuk hozzászólásaikat közleményeinkhez, amelyet bejelentkezés után a weboldalon, vagy közösségi média oldalunkon tehetnek meg.

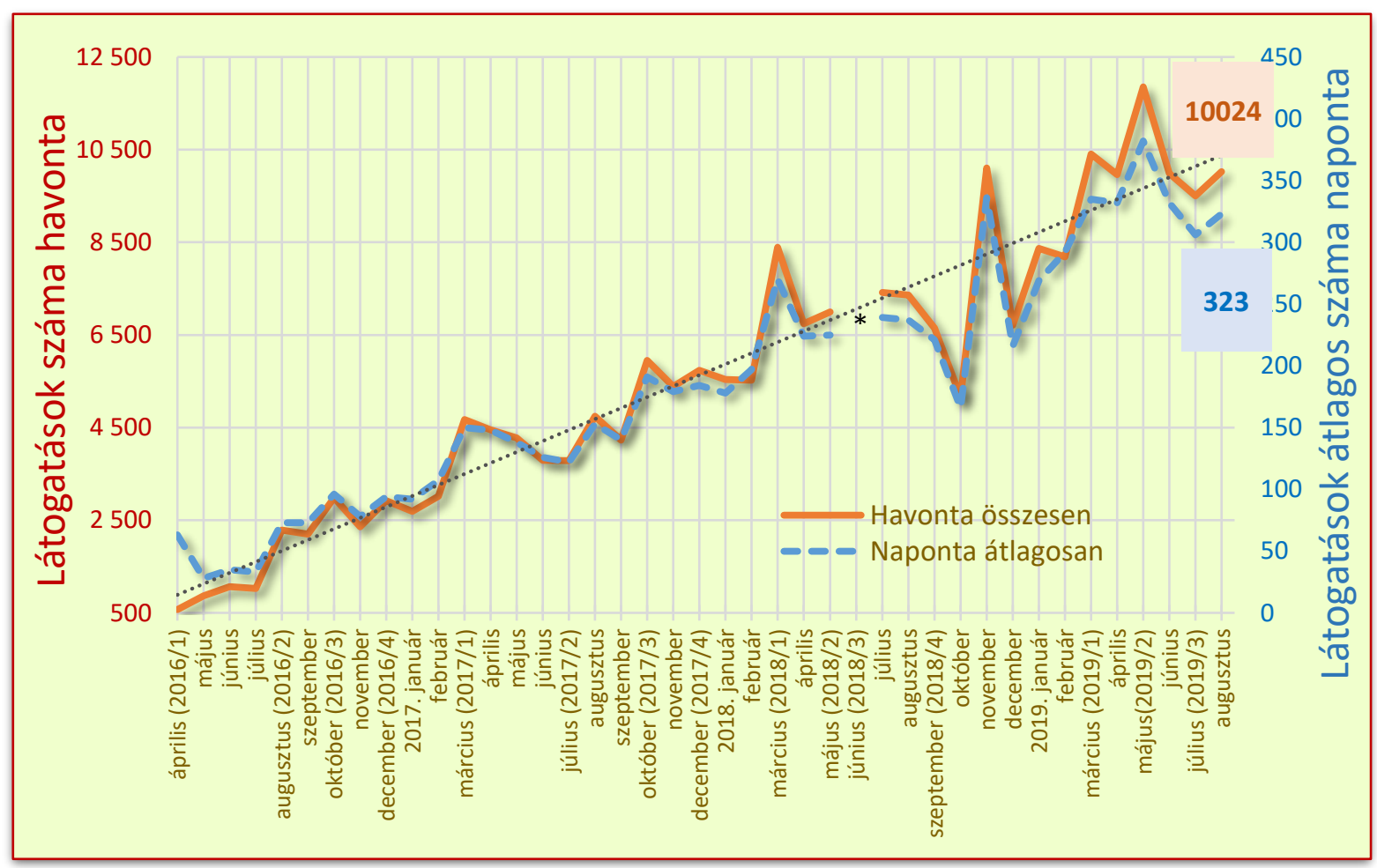

* nincs adat 


\begin{tabular}{|c|c|c|c|}
\hline $\begin{array}{l}\text { Megtekin- } \\
\text { tések } \\
\text { száma }\end{array}$ & Közlemény címe & Szerzők & Lapszám \\
\hline \multicolumn{4}{|c|}{ ÖSSZEFOGLALÓ } \\
\hline 828 & Egészséges életmóddal kapcsolatos kutatások a hazai iskolákban & \begin{tabular}{|l} 
Járomi É, Szzlágyi K, \\
Vitrai J
\end{tabular} & 2016. 1. \\
\hline 696 & A kortársbántalmazás (bullying) mint népegészségügyi probléma & $\begin{array}{l}\text { Várnai D, Zsíros E, } \\
\text { Németh Á }\end{array}$ & 2016. 4. \\
\hline 662 & Hazai egészség-pillanatkép, 2017 & $\begin{array}{l}\text { Vitrai J, Bakacs M, } \\
\text { Varsányi P }\end{array}$ & 2017. 4. \\
\hline 574 & $\begin{array}{l}\text { Kortárs egészségfejlesztési programok gyermekek és fiatalok körében a hazai és a } \\
\text { nemzetközi szakirodalom tükrében - Szisztematikus áttekintés }\end{array}$ & Lukács-Jakab Á et al. & 2018. 1. \\
\hline 567 & A magyarországi egészségértés nemzetközi összehasonlításban & Kolta J, Kun E & 2016. 3. \\
\hline 547 & $\begin{array}{l}\text { A 2015/2016. tanév országos fittségmérési eredményei a Nemzeti Egységes Tanulói } \\
\text { Fittségi Teszt (NETFIT®) alapján }\end{array}$ & Csányi T, Kaj M & 2017. 4. \\
\hline 545 & $\begin{array}{l}\text { A gyógytestnevelés jelentősége a szekunder rehabilitáció és egészségfejlesztés } \\
\text { folyamatában, megújulásának szükségessége, irányai }\end{array}$ & Simon I, Kajtár G & 2018. 1. \\
\hline 540 & Az egészségmúveltség definíció & Csizmadia P & 2016. 3. \\
\hline 498 & $\begin{array}{l}\text { Az egészségügyi ellátáshoz való hozzáférés területi egyenlőtlenségeinek vizsgálata az akut } \\
\text { miokardiális infarktus okozta halálozás adatainak felhasználásával }\end{array}$ & $\begin{array}{l}\text { Uzzoli A, Vitrai J, } \\
\text { Tóth G } \\
\end{array}$ & 2017. 3. \\
\hline 485 & Az iskolai egészségfejlesztés hazai és nemzetközi szemléletének bemutatatása & Járomi É, Vitrai J & 2017. 1. \\
\hline \multicolumn{4}{|c|}{ TELES KÖZLEMÉNY } \\
\hline 3093 & A csecsemőkori allergia-megelőzés korszerú irányelvei és lehetőségei & Réthy A & 2017. 1. \\
\hline 1389 & Egészségfejlesztési Irodák hálózata & Bezzegh P & 2016. 1. \\
\hline 1154 & Egészséges életmóddal kapcsolatos kutatások a hazai iskolákban & $\begin{array}{l}\text { Járomi É, Szilágyi K, } \\
\text { Vitrai J }\end{array}$ & 2016. 1. \\
\hline 709 & Hazai egészség-pillanatkép, 2017 & $\begin{array}{l}\text { Vitrai J, Bakacs M, } \\
\text { Varsányi P }\end{array}$ & 2017. 4. \\
\hline 680 & Magyarország népegészségügyi rendszere és egészségfejlesztéssel foglalkozó szervezetei & Túri G et. Al & 2018. 2. \\
\hline 640 & OKOSTÁNYÉR ${ }^{\oplus}$ - új táplálkozási ajánlás a hazai felnőttt lakosság számára & Szúcs Zs & 2016. 4. \\
\hline 445 & $\begin{array}{l}\text { Összefoglaló „A munkahelyi egészségfejlesztés általános szervezeti megvalósitására } \\
\text { vonatkozó szakmai útmutató”-ról }\end{array}$ & Solymossy J, Koós T & 2016. 3. \\
\hline 440 & Amerikai Táplálkozási Ajánlás 2015-2020 - rövid ismertetés & Fekete K, Henter I & 2016. 2. \\
\hline 433 & $\begin{array}{l}\text { Energiaital fogyasztási szokások és egészségtudatosság a felsőfokú képzésben résztvevő } \\
\text { hallgatók körében }\end{array}$ & $\begin{array}{l}\text { Dojcsákné Kiss-Tóth } \\
\text { É, Kiss-Tóth E }\end{array}$ & 2018. 4. \\
\hline 431 & A magyarországi egészségértés nemzetközi összehasonlításban & Kolta J, Kun E & 2016. 3. \\
\hline \multicolumn{4}{|c|}{ "ÉRDEKESSÉG" } \\
\hline 3,46 & A csecsemőkori allergia-megelőzés korszerű irányelvei és lehetőségei & Réthy A & 2017. 1. \\
\hline 1,41 & Magyarország népegészségügyi rendszere és egészségfejlesztéssel foglalkozó szervezetei & Túri G et al. & 2018. 2. \\
\hline 1,41 & A fizikai aktivitás, mint egészségbefektetés & $\begin{array}{l}\text { Gabnai Z, Müller A, } \\
\text { Bács Z, Bácsné Bába É }\end{array}$ & 2019. 1. \\
\hline 1,27 & $\begin{array}{l}\text { Energiaital fogyasztási szokások és egészségtudatosság a felsőfokú képzésben résztvevő } \\
\text { hallgatók körében }\end{array}$ & $\begin{array}{l}\text { Dojcsákné Kiss-Tóth } \\
\text { É, Kiss-Tóth E }\end{array}$ & 2018.4. \\
\hline 1,14 & Egészségfejlesztési Irodák hálózata & Bezzegh P & 2016. 1. \\
\hline 1,14 & Hazai egészség-pillanatkép, 2017 & $\begin{array}{l}\text { Vitrai J, Bakacs M, } \\
\text { Varsányi P }\end{array}$ & 2017. 4. \\
\hline 0,96 & $\begin{array}{l}\text { Az egészségtervezés és az egészségfejlesztési tervezés módszereinek közös pontjai és } \\
\text { különbségei }\end{array}$ & Márovics G & 2019. 3. \\
\hline 0,95 & Egészséges életmóddal kapcsolatos kutatások a hazai iskolákban & \begin{tabular}{|l|} 
Járomi É, Szilágyi K, \\
Vitrai J \\
\end{tabular} & 2016. 1. \\
\hline 0,93 & A gyermekkori elhízás népegészségügyi vonatkozásai & Kovács AV & 2018.4. \\
\hline 0,82 & Vitaindító: Miért és hogyan kellene a hazai népegészségügyet megújítani? & Vitrai J & 2019. 2 . \\
\hline
\end{tabular}

